\title{
Toddlers as social actors in early education
}

\author{
Los niños pequeños como actores sociales en la \\ educación infantil temprana
}

\section{Crianças como atores sociais na educação infantil}

\author{
Ingrid Maria Engdahl \\ ORCID ID: 0000000349354216 \\ Stockholm University, Suecia
}

Autor referente: ingridengdahl@gmail.com

Historia editorial

Recibido: 22/03/2021

Aceptado: 14/04/2021

\begin{abstract}
This article focuses on the interaction among young toddlers during their second year of life in a Swedish preschool, with the view of toddlers as social actors. The overall aim is to explore interaction, communication, and the creation of friendship between the young children during self-initiated play activities. Play is looked upon as a rich arena for observing toddler interaction. The theoretical framework for the study is phenomenology, the view of the child as a social person and a child-oriented perspective. This article will also address the important concepts of methodology and research ethics, in relation to an ethnographic early childhood study, intended to investigate toddler's life worlds. A close analysis of their worlds may reveal what was not visible before - like a kaleidoscope. Six
\end{abstract}

one-year-old girls and boys in a setting, in a total of 15 children, were the focus of this study's observations for nine months. Participatory methods, photos, field notes and video-recordings, were used for the data collection.

The findings of the ethnographic study recognise theoretically the competence of the toddler as a social actor, the child as an active participant, and the strategic nonverbal and verbal actions of children to initiate friendship. Mutual awareness, joint attention, shared smiles, coordinated movements, as well as other types of synchronized actions are understood as parts of nonverbal elements in emerging friendship. The competencies of attunement, taking others' perspectives and turn-taking were found in play among the young toddlers.

Keywords: Early childhood education and care; toddlers; competencies; social persons. 


\section{RESUMEN}

Este artículo se centra en la interacción entre los niños pequeños durante su segundo año de vida en un preescolar sueco, desde la perspectiva de los niños pequeños como actores sociales. El objetivo general es explorar la interacción, la comunicación y la creación de amistad entre los niños pequeños durante las actividades de juego iniciadas por ellos mismos. El juego se considera un campo rico para observar la interacción de los niños pequeños.

El marco teórico para el estudio es la fenomenología, la visión del niño como una persona social y desde un enfoque centrado en el niño. Este artículo también abordará las categorías centrales de metodología y ética de la investigación, con relación al estudio etnográfico de la primera infancia, destinado a investigar los mundos de la vida de los niños pequeños. Un análisis detallado de sus mundos puede revelar -como un caleidoscopio- lo que antes no era visible. En un grupo de quince niños, se enfocó el estudio de seis niñas y niños de un año en el entorno preescolar mediante observaciones desarrolladas durante nueve meses. Para la recolección de datos se utilizaron métodos participativos, fotografías, notas de campo y grabaciones de video.

Los hallazgos del estudio etnográfico reconocen teóricamente la competencia del niño pequeño como actor social, el niño como participante activo, y las acciones estratégicas no verbales y verbales de los niños para iniciar la amistad. La conciencia mutua, la atención conjunta, las sonrisas compartidas, los movimientos coordinados, así como otros tipos de acciones sincronizadas, se entienden como parte de elementos no verbales en la amistad emergente. Las competencias de sintonía, considerar las perspectivas de los demás y tomar turnos, fueron halladas en el juego entre los niños pequeños.

Palabras clave: Educación y cuidado de la primera infancia; niños pequeños; competencias; sujetos sociales.

\section{RESUMO}

Este artigo enfoca a interação entre crianças pequenas durante o segundo ano de vida em uma pré-escola sueca, com a visão das crianças como atores sociais. O objetivo geral é explorar a interação, a comunicação e a criação de amizade entre as crianças pequenas durante as atividades lúdicas autoiniciadas. As brincadeiras são vistas como uma arena rica para observar a interação das crianças.

O referencial teórico do estudo é a fenomenologia, a visão da criança como pessoa social e uma perspectiva orientada para a criança. Este artigo também abordará os conceitos importantes de metodologia e ética em pesquisa, em relação a um estudo etnográfico da primeira infância, destinado a investigar o mundo da vida de crianças pequenas. Uma análise detalhada de seus mundos pode revelar o que não era visível antes como um caleidoscópio. Em um grupo de quinze crianças, o estudo de seis meninas e meninos de um ano de idade no ambiente pré-escolar foi focado por meio de observações desenvolvidas ao longo de nove meses. Métodos participativos, fotos, notas de campo e gravações de vídeo, 
foram utilizados para a coleta de dados.

Os resultados do estudo etnográfico reconhecem teoricamente a competência da criança como ator social; a criança como um participante ativo, e as ações não-verbais e verbais estratégicas das crianças para iniciar a amizade. Consciência mútua, atenção conjunta, sorrisos compartilhados, movimentos coordenados, bem como outros tipos de ações sincronizadas são entendidos como partes de elementos não-verbais na amizade emergente. As competências de sintonização, assumir a perspectiva dos outros e dar turnos foram encontradas em brincadeiras entre as crianças pequenas.

Palavras-chave: Educação e cuidados na primeira infância; crianças; competências; pessoas sociais.

ccording to the National Curriculum for the Preschool (National Agency for
Education, 2018), the Swedish preschool is founded on a comprehensive and holistic view of children. The preschool strives for a pedagogical approach, where care, nurturing and learning together form a coherent whole. The education shall be ‘enjoyable, secure and rich in learning for all children' (National Agency for Education, 2018, p. 7). Preschools are open all year round and daily opening times are varied to fit in with the parents' working hours or study schedules. Preschools can be run by municipalities, companies, parent cooperatives or by non-profit organisations. The preschool groups are organised locally and can consist of mixed ages (1-5 years), toddlers (1-3-year-olds), older pre-schoolers (3-5-year-olds) or of age specific groups $(1,2,3,4$ and 5 years old). The professionals work in teams of two-four teachers and childcare attendants, with responsibility for a group of children. Around $40 \%$ of the staff has a university degree in education, and around $30 \%$ have completed professional training in the secondary school (National Agency for Education, 2020).

In Sweden, most children start preschool during their second year of life. Today around $80 \%$ of the two-year-olds and $90 \%$ of the three-year-olds and $95 \%$ of the $4-5$-year-olds participate in preschool education. Swedish pre-schools are most often run by the municipalities. They offer a full day programme, and the parents choose how many 
hours per day their child will spend in preschool. The new situation, with high numbers of toddlers being raised both in their family and in their preschool, can give young children access not only to more adults, but also to multiple peer relationships outside their families. Early childhood in Sweden today is lived both at home and in preschool, which is a larger transformation from a historical and societal perspective.

During the last few decades children in western countries have been increasingly recognised as human beings with rights. This development may in part be understood by the adoption and implementation of the UN Convention on the Rights of the Child (UN, 1989). The position of the child in most countries has been altered, and that children are looked upon as citizens. The changed view of children is also reported in research, where children are understood from the perspective that they influence and are influencing their life-world (see for example Sommer, Pramling Samuelsson \& Hundeide, 2010; Višnjić Jevtić, Sadownik, \& Engdahl, 2021). These studies explore children's social competencies, as well as their relationships with siblings, peers, parents and teachers and guiding policies. As most studies of children in preschool look at 3-5-years-olds, this study focused on toddlers, children aged 1 and 2 years (Engdahl, 2011a).

The aim of the study was to explore interaction and communication between young children during self-initiated play activities in a Swedish preschool. The youngest children, the toddlers, are in focus, and among them, the youngest toddlers, aged between 13 and 24 months during the study, have received special attention. The study took place during play and play is looked upon as a rich arena that makes toddler research possible. The following questions informed the study:

- How do these young children express themselves when playing with peers and more specifically, how do they interact and communicate with each other?

- How do they create friendship and what type of actions do they use in such a process? 
The rationale of the study is to produce and share knowledge about toddlers' life in an educational setting. As today, a large and increasing number of toddlers are enrolled in preschools, it is important to critically examine this part of their life-worlds. Methodological aspects are described in a later section.

Let us now visit one of the toddlers in the study. Nova is a girl of 16 months, who has just started preschool. During her third week, this episode takes place. The children are outside playing in the morning. Nova is sitting in a sand pit quite close to an educator who is in charge of Nova's introduction period in the preschool. Elliot (26 months) is a peer from the same group.

Nova is playing in the sandpit. She puts some sand into a cup and then taps hard with the spade, saying: 'tap, tap'.

Elliot comes up to Nova, face to face with a smile and says: 'Good morning, Nova', while looking into her eyes and patting her cheek.

Nova looks at Elliot, takes off her cap and gives it to Elliot, smiling at the same time. Elliot takes the cap, tries to put it on, but it was too small! Both children laugh.

Elliot puts Nova's cap back on her head. Nova smiles again at Elliot who leans over, very close to Nova's face and he says 'Hello, Nova, come preschool'. This observation shows the experience Nova got as a newcomer in the preschool. Most children passed by and greeted her in different ways while she was sitting and playing in the sandpit. She was welcomed, she was recognised, and she seemed to enjoy the friendly atmosphere and actions, as the one Elliot enacted. Episodes like these show the social competence of toddlers, who, without instructions, act as quite skilled play mates, peers and friends-to-be. This article is about this group of people. 


\section{Theoretical perspective}

\section{Phenomenology - a holistic approach}

Phenomenology was chosen as a theoretical and methodological framework to accomplish close descriptions of the phenomena studied, elucidating both what appears and the ways in which it appears (Merleau-Ponty, 1962). Striving for the close descriptions help to balance influences based on presuppositions and biases and to widen the understanding of individuals or groups of people through the relationships and actions they carry out in their environment. Within phenomenology, the focus is on different perceptions of phenomena. Individuals may perceive reality in various ways which consequently lead to different actions. With its descriptive and qualitative approach, phenomenology encourages the researcher to strive for close, immediate descriptions of original experiences (Willig, 2008).

The phenomenological term life-world refers to what appears in everyday life and it represents a direct and immediate experience, independent of and before explanations (Merleau-Ponty, 1962). It is described as subjective and objective at the same time. How we perceive the world depends on our previous experiences, which implies that individuals create his or her own conception of the world. Thus, the life-world represents something more than the mere sum of physical facts and is seen as a complex and multifaceted phenomenon. In addition, it accommodates both physical experiences and changing qualities of values, meanings, and traditions. Merleau-Ponty (1962) described the life-world as pre-reflective; it both precedes and is a precondition for thoughts and reflections. That is why the life-world cannot be reduced to physical objects. Instead, the experiences of nature, culture, society, history, and subject units are perceived as intertwined (Willig, 2008). 


\section{Children as social persons}

In this study, children are understood as social persons. From this perspective the toddlers may be perceived as actors and subjects with social purposes, goals, and intentions (Meadows, 2010). Being a social person includes an active development of social skills. A variety of coping strategies seems to promote social agency. How children cope with strong emotions or stress, for example, have impact on their mental health and their achievements (Meadows, 2010).

Children are increasingly described as being born with a social competence of togetherness, and socialisation is seen as a process where the relatively competent human being is capturing and handling the surrounding society and culture in an active and continuous way (Sommer et al., 2010). This may also be understood from a relational perspective, stressing the importance of qualitative relationships between people.

Researchers from various perspectives agree on that the first three years of life are critical for children's development and well-being (Meadows, 2010). The care of young children is highly specialised and challenging work, and the teachers' approach and involvement are the most important quality factor (Sylva, Melhuish, Sammons, SirajBlatchford, \& Taggart, 2010). When staff members are emotionally stressed, this affects their work and the children, and may result in rigid routines and practices (Gray, 2004; Johansson, 2004).

\section{The toddler}

The term toddler is described as related to age; a child between one and three years old, but it is also linked to a certain embodied style with special body movements and a certain way of walking. Løkken (2000) described a special toddling style recognised by running, jumping, trampling, twisting, bouncing, romping, and shouting, falling, and laughing. Toddlers' ways of being together are characterised by mutuality, 
embodiment, freedom, spontaneity, and joy. There seems to be a tacit understanding between toddlers, and they are social and involved in establishing cultural patterns and norms in preschool settings (Engdahl, 2007; Løkken, 2000).

Recent studies of children's ways of acting, reacting, behaving, and learning have produced a somewhat different picture of children's abilities (Engdahl, 2007; Sommer et al., 2010). Studies of infant development have, for example, shown that a child can be socially active from the first minutes of its life and that learning can take place in interaction with others in meaningful contexts (Stern, 1985). These results indicate that infants are aware of and interested in other persons.

Stern $(1985,1990)$ found that children have an emergent sense of self from birth, and they develop more senses (in his terminology a core sense, a subjective sense, and a verbal sense) during interpersonal lifelong processes of communication. Already during their first year in life, infants show a beginning competence for emotional attunement with the caregiver, and an emerging insight of other persons' feelings in a shared situation. Inter-play, co-existence and mutuality are other competencies growing already from a child's first year in life.

Stern's theory recognises, for example, that development and learning are processes that always involve feelings. Cognitive aspects and thoughts are not isolated phenomena since the whole child, body, mind, and soul, is involved in these processes (Stern, 1985, 1990). Stern's concept the present moment (Stern, 2004) points to the importance of the lived experience of phenomena in the life-world. The feelings perceived in the present moment are looked upon as an existential force. The present moment consists of a subjective, psychological unit of which the perceiving person is totally aware. It is brief (4-10 seconds), uninterrupted, grouping many small meaningful perceptions in a specific context. The present moment can, according to Stern, be considered as the fundamental building stone for creating experiences of relationships. 
From the 1990s, the preschool child has increasingly been looked upon as a learner, as a thinking human being who poses questions and explores the surrounding world. Learning may take place anywhere and at all times but does not necessarily follow the intentions of the adults. Children develop learning strategies in interaction with the environment, and they are described as capable of solving problems (Pramling et al., 2019).

Other children, as well as adults, are of importance for learning and development (Engdahl, 2012; Williams, 2001). Participants in a learning process adjust themselves in varying and complementary ways to reach a common understanding, a mutual bridging of meaning.

\section{A child-oriented perspective}

Another important source of inspiration for this study comes from the field of childhood sociology. Different childhoods are constructed through the societal conditions and children's actions (James \& Prout, 1990). In addition, qualitative differences exist between the ways children and adults are influenced by societal changes. Childhood is seen as a social institution where children participate, constitute, and are constituted by their social worlds. Children learn from the adult's world and they reciprocally influence the adult culture, while at the same time they also participate in and produce their own culture.

Recognising children as human beings draws on a fundamental respect for the child as a subject with rights, and with a right to influence the situation at hand (UN, 1989; Višnjić Jevtić et al., 2021). Studying children from a child-oriented perspective is "an attempt to direct adults' attention towards an understanding of children's perceptions, experiences, and actions in the world" (Sommer et al., 2010, p. 22), by getting close to and gaining insight into their worlds. Corsaro's research within micro-sociology (2003) can be understood as carried out with a child-oriented perspective. The children, even 
as young as toddlers, can describe what they perceive as important in the adult world and, also the rules they make up themselves (Corsaro, 2003; Johansson, 2004).

\section{Integrating play and learning within early childhood education}

Early education has the ambition to give children as rich experiences and opportunities as possible. The children's competencies are related to and challenged by the affordances in the physical and psychological environment (Engdahl, 2007). Play is an integrated part of early childhood education, but the role of play has been defined in different ways. Play has been described as an opportunity for children to go beyond their daily behaviour. For instance, children in play climb up to positions where they are a head above their height (Vygotsky, 1978). Play can in addition serve as an opportunity for children to learn how to understand their surrounding world, to practice and can enhance learning about themselves and others (Pramling et al., 2019). The essence of play can also be understood as an opportunity to deal with reality on a child's own terms, or as an activity where young children's inner world can develop, for example, through the child's use of imagination and fantasy. Young toddlers play all through the day (Engdahl, 2011a). From this perspective, young children may be active in developing relationships with friends, especially while playing. Play is motivated both by the children's own intentions and by affordances in the surrounding environment (Engdahl, 2007).

Friendship has been defined as a mutual relationship, characterized by companionship, intimacy, and affection by Howes (1983) who defines friends as children who enjoy and prefer playing together. Friendship can be seen as a voluntary relationship, confirmed by both parties, including reciprocity as well as mutuality of affection. In addition, friendship is seen as related to closeness, sharing of emotions, both positive and negative, as well as familiarity (Engdahl, 2012). Friendship can, however, not be taken 
for granted and does not develop automatically, compared to relationships with parents, sisters, and brothers.

\section{Methodology and ethics}

Within an ethnographical study with young toddlers, it is important to get to know the children by giving them attention, to be mentally present and at the same time to give room for the children to get to know the researcher (Løkken, 2000; Johansson, 2004). Participatory observation was chosen as it allows closeness to the children, which can be seen as a necessity in a study with a child perspective (Sommer et al., 2010). The methods in a phenomenological study shall be as open and exact as possible, striving for unveiling also what is not obvious (Merleau-Ponty, 1962; Willig, 2008).

My attention was towards children's perceptions, experiences and actions and I consciously strived to get close to and gain insight into their worlds. By carefully listening, observing, and analysing the ways in which children communicate, researchers may develop a better understanding of how children make sense of their lives (Farrell, 2005). Inspired by Emerson, Fretz and Shaw (1995) I used field notes together with photos, video recordings and a diary as methods instead (Willig, 2008).

\section{Research ethics}

I was careful about ethics, concerning information and consent. As a vast majority of the parents had another mother tongue than Swedish, it was not considered enough to just send home written information (Farrell, 2005). The quality of a phenomenological study is interrelated with the relationships and the trust that can be built between the participants and the researcher. It was important for me to become an accepted partner.

Thus, the question of using interpreters in my communication with the parents or not was highly relevant. Acting on the teachers' information, my decision was to follow the 
ordinary routines for parent cooperation, which were based on small group conversations, where other parents often served as facilitators.

A detailed form for parents' consent was put together as there is a growing concern among teachers and parents about the risk of not having the recordings under proper control (Farrell, 2005). It was also important for me to clarify that the consent could be withdrawn at any time and that the data should be treated confidentially. All participants were given new names and the preschool, as well as the suburb was not identified throughout the process.

The study was carried out with a child-oriented perspective, which made it important to get informed consent also from the children. Young children have the right to be listened to and to make decisions about things that influence their daily lives (National Agency for Education, 2018; UN, 1989). Each day, when doing my observations, I asked them if it was OK. I tried to be observant of their body language and their signals, which clearly can indicate acceptance, opposition, or denial (Farrell, 2005).

\section{The preschool context}

The study was carried out in a municipal preschool in a multicultural suburb in Stockholm, Sweden, during March-November, 2006. The preschool was chosen by the municipal head of education in this area, from a group of preschools that had volunteered to be part of this study. The number of preschool children from families with a foreign background is high (80\%) and growing. The preschool was built in 1979 and is a typical example of preschools from that period. It is located in a park, a short walk from the underground station, in an area with apartment houses.

There are four units in the preschool, two for toddlers (1-3-year-olds) and two for older children (3-6-year-olds). The study was conducted within one toddler unit with, in total, 15 children. Two preschool teachers (full time) and two child care attendants (part time) work together in this unit; together they work between 7 am and $6 \mathrm{pm}$. 
The in-door facilities are inviting and fresh, due to recent renovation, with furniture, materials, and toys chosen for toddlers. The out-door playground is large, partly natural, partly constructed, with sandpits, climbing frames, small houses, slides, asphalt, and grass. The playground is surrounded with a low fence, and it is a possible to divide the playground into two, with the help of a gate.

The 15 children in the studied unit were between 14 and 36 months old during the study. The six youngest children (13-24 months), Theo, Nova, Leo, Robin, Molly and Jasmine were the focus of my observations, while the other nine older toddlers also participate as peers, and sometimes are participating in my observations.

\section{The methods}

Helping me to keep the child-oriented perspective, each day I chose one of the children to be in focus for the observations that day. This way, I stayed with one child, no matter what interesting things that happened in other places. The child showed me his or her way around the premises. Other children became part of the observations when they shared the focus child's games or activities. Self-initiated play sequences and nonstructured activities were chosen for observations, that is, when the toddlers were able to decide about their own actions. This intention ruled out teacher-initiated activities and daily routines. Children in the Nordic countries play outside every day, but there are few studies about toddlers' outdoor play. As most early childhood education studies are made indoors, I chose to observe both during indoor and outdoor activities.

The analysis in a phenomenological tradition strives for rich, intense, and complete descriptions, which draw on precise observations (Willig, 2008). With close descriptions it might be possible to document things that are not so obvious and hard to notice in the routines and in the environment.

The field-notes and the photos were transcribed continuously with special attention given to contact, communication, interplay and emerging friendship phenomena. The 
video observations of the play sequences were transcribed action by action, and later a detailed transcription was made of sequences that were considered being of special interest for the study.

\section{Results}

The analysis of the observations resulted in three phenomena showing toddler competencies in play among the young toddlers: turn-taking, taking another child's perspectives, and emerging friendship. Aim, research questions and results will be further analysed in the Discussion.

\section{Turn-taking}

The toddlers were communicating in multiple ways, using body, sound, speech, and movement. Many turns in a sequence of turn-taking were frequent but needed the careful and close observations to be found. The following example (videotaped November 30, Engdahl, 2011b) shows a situation full of social and educational learning. Theo (17 months) had only been in the preschool for some weeks, when one morning he was busy out-doors exploring a bench which is attached to a wooden playhouse. Theo was working intensely on climbing up and down the bench. He also tried to stand up and to sit down on the bench. Max (an older peer, aged 2.5 years) approached him:

Theo climbs up on the bench on his knees and then stands up

Max comes up to the playhouse, stops and looks at Theo,

walks up to the bench and climbs up on the bench

Theo looks at Max and laughs

Max looks at Theo, laughs, climbs down,

walks away a few steps, then turns around and looks at Theo

Theo looks at Max and stamps his foot on the bench 
Max stamps his foot on the ground, looking at Theo

Theo laughs

Max laughs and stamps

Theo stamps and laughs

Max returns to the house and joins Theo on the bench and climbs up

Theo smiles at Max

(Engdahl, 2011b, p. 10)

Analysing this observation showed the turn-taking that went on between the two boys. One of the children made a move, acted, and another child noticed the action and repeated or imitated it. The action was observed by child number one, who in turn made a move, followed by careful observations and new actions from child number two. The happy laughter was a welcoming confirmation of Max's approach. When Max climbed down, Theo looked at him and made an initiative by stamping his foot on the bench. Then Max took up on the invitation and stamped his foot on the ground, and the happy laughter was there once more. This improvisational play included motoric, social, and emotional learning.

Most of the play turn-takings of the studied young toddlers were manifested in physical action. With the help of eye contact, the children seemed to focus on each other closely, they took in the situation and adapted to the peer's next action. This can also indicate an emerging competence of taking the perspective of the other, which was the next finding.

\section{Taking another child's perspective}

The analysis of data showed that the toddlers studied each other carefully, and at times also took another child's perspective. This phenomenon was an interesting result, as it showed that young toddlers have social and cognitive skills that seldom are reported in research (Engdahl, 2011a). 
The following observation was made one morning when Leo (21 months) and Robin (21 months) were indoors playing with various things. There was a hammock hanging low from the ceiling in the large playroom. Leo and Robin were both being helped into the hammock by a teacher. Leo and Robin were lying down facing each other. Leo had Robin's legs on each of his sides and Robin had Leo's feet under his own legs. The hammock was swinging slowly, and the boys were swinging along when the following episode developed:

$\begin{array}{lll}1 & \text { Robin } & \text { laughs and kicks his feet towards/into L } \\ 2 & \text { Leo } & \text { kicks his feet towards R } \\ 3 & \text { Robin } & \text { kicks, then lies still, } \\ 4 & & \text { laughs and starts kicking faster } \\ 5 & \text { Leo } & \text { kicks and stops } \\ 6 & \text { Robin } & \text { says': 'ah, sch, sch, sch, sch' and kicks } \\ 7 & & \text { [quick glance at me] } \\ 8 & \text { Leo } & \text { kicks and looks at R } \\ 9 & \text { Robin } & \text { pauses, resumes the kicking and says: 'sch, sch, sch' } \\ 10 & \text { Leo } & \text { looks at R and } \\ 11 & & \text { turns his body so that both R's feet kick his butt } \\ 12 & \text { Robin } & \text { kicks } \\ 13 & \text { Leo } & \text { smiles and says: 'ah ha aHA: a' turns and } \\ & & \text { meets R's left foot with his right foot } \\ 15 & \text { Robin } & \text { kicks towards L's feet, stops, laughs and kicks } \\ 16 & \text { Leo } & \text { smiles, uses his hands to block R's kicking feet, } \\ 17 & & \text { looks into R's eyes, smiles and kicks } \\ 18 & \text { Robin } & \text { looks into L's eyes } \\ 19 & \text { Leo } & \text { grabs R's foot and says: 'eh hehe' } \\ 20 & \text { Robin } & \text { kicks again and says: sch, sch, sch, sch' } \\ 1 & & \text { D. } 11)\end{array}$

(Engdahl, 2011b, p. 11) 
The boys swinging in the hammock first seemed to be with the aim to rest. Then Robin started kicking. Leo's response was kicking with his feet towards Robin. The turn-taking kicking went on in a reciprocal way (lines 1 to 8). The kicking was accompanied by 'sh, sh, sh, sh' - sounds from Robin, and with smiles and laughter from both boys. The kicking appeared to be ticklish and fun, and the boys laughed and looked at each other. The kicking seemed to be accepted by both boys; however, their kicking was on the verge of becoming violent. There were frequent stops and pauses (lines 3, 5, 9 and 15). During the breaks in the kicking activity, the boys looked carefully into each other's eyes, until one or the other resumed his kicking (lines 8 and 17). During this sensory motoric interaction, the boys communicated through these moments of eye contact, adapting the quite rough body movements to each other's reactions. The breaks can be understood as moments for taking the perspective of the other (lines 3, 5, 9 and 15).

\section{In the voice of the child}

Most adults seem to underestimate the competences of toddlers. By adding the Iperspective, the thoughts and feelings may be included, and this may imply more detailed discussions about my results. Thus, inspired by Stern (1990), I sometimes choose to tell the observations in the children's voice (Engdahl, 2007). By this I mean that I consciously transcribe the observations into narratives, appointing the focus child in the observation as the I in the story. There are several reasons for doing this. Firstly, a narrative encompasses a more genuine and holistic description of the situation. Secondly, by also giving the child a voice and writing the transcription with the child as I, the narrator, I manage to include sentiments and feelings into the narratives. Thirdly, during my study, it was obvious how emotional and social the toddlers are. These additional languages tend to be left out with ordinary transcriptions.

The following episode from August 15, illustrates non-verbal communication between two toddlers, and the phenomenon of taking the other's perspective. Leo (18 months) 
was the day's focus child, and thus I had given him the role of narrator of this story. Leo is outdoors and has just found a carriage. But Oliver had his eyes on the same carriage (30 months):

Today, we were outside, playing with the cars in the playground. Then I saw a carriage and I so wanted to have that carriage. I grabbed the handle.

I was just about to start pushing when Oliver came up to me, looking at me, and he wanted to have the carriage! I let go and picked up a car instead.

Oliver went away, pushing the carriage in front of him. I looked towards him but then I decided to go after him.

I went up to Oliver and let go of my car. I looked very intensely at Oliver and then, he let go of the carriage!

He understood that I wanted it! I took the carriage - and then Oliver picked up my car and started to play away with it. He drove down the hill to the fence.

And me, I took the carriage and followed him.

(Engdahl, 2007, p. 73)

Without exchanging words, the two toddlers seem to understand each other well. During the short non-verbal meetings, they looked intensely at each other and it seemed as if they were taking each other's perspective. This situation was interesting, because the two boys seemed to handle a situation that otherwise could have led to a problem.

\section{Emerging friendship}

The third phenomenon that came out of the analysis showed how these young toddlers create emerging friendships: The one-year-olds monitored and paid attention to individual peers, displaying intentionality and agency. The young toddlers spontaneously greeted other children, and they used or recognised their names. The greetings and hugs appeared to strengthen the perception of the individuality of the 
peers and may be understood as the beginnings of friendship. They used a variety of actions to get in contact with or to start playing with another child. They were inviting their peers to interplay, offering toys and to help their peers. The one-year-olds recurrently looked for special children who could become peer companions in the play. All these social actions were spontaneous initiatives by the child himself/herself, directed at another child, and they primarily took place nonverbally. The overall findings support a theoretical perspective where the young children are understood as social actors, with intentions, social preferences, and social competences. The young toddlers demonstrated consistent interest in each other.

The toddlers chose to play as soon as they got the chance. I saw several examples daily that play attracted, they gathered in and around on-going play. Traditionally, toddlers' play is often described as imitation, side play and parallel play. In today's expanded preschool activities, there are ample opportunities for social communication where the toddlers also invite each other to play, a social action that has not received enough attention in previous research. In the following example, Robin invited Leo to play, using body language and toys:

Robin is playing with trucks. He holds one small and one large truck in his hands.

Robin drags both trucks along and walks up to Leo.

He stops in front of Leo and looks at him.

Leo looks at Robin.

Robin gives the small car to Leo and walks away towards the hill, while at the same time looking at Leo.

Leo follows Robin with his eyes. Robin walks a few more steps, and then stops, looking intensely at Leo.

Leo walks up to Robin and together they mount the small hill.

(Engdahl, 2012, p. 92) 
Robin invited Leo to play by bringing and offering him a car. With his body language he showed his idea that they should play together with the cars on the slope. While Robin walked towards the hill, he was still half turned to Leo and kept looking at him. Leo seemed to understand Robin's invitation to play. When Leo was following Robin, this can be understood as if he was accepting the invitation, and the boys confirmed the mutuality in the agreement by their joint play. As it can be seen, this involved multimodal play invitations: a 'gift exchange' (the car), mutual gaze, shared attention, and joint locomotion, actions that may be interpreted as the origins of friendship. Being seen and selected, getting an invitation to play are important actions in both identity development and relationship building. Friendship grows in play through the directed attention and in the shared experiences (Engdahl, 2012).

\section{Discussion}

The aim of the study was to explore interaction and communication between toddlers during self-initiated play activities in a Swedish preschool. The study took place during play and play is looked upon as a rich arena that makes toddler research possible. The research questions will be used to structure this discussion.

\section{How do these toddlers express themselves when playing with peers and more specifically how do they interact and communicate with each other?}

The findings show the toddler as a social actor; the child as an active participant, the strategic nonverbal and verbal actions of children to initiate friendship and the value of theory that investigates life-worlds in the everyday context. Mutual awareness, joint attention, shared smiles, coordinated movements, as well as other types of synchronized actions are understood as parts of nonverbal elements in emerging friendship. Based on this and previous studies with pre-schoolers, there is a need to stress the importance of play in early childhood education. The findings from this study 
indicate that child-child interaction, and time for self-initiated activities can be crucial for developing social skills in how to interact with peers.

For many children, the preschool represents a substantial part of their everyday life. Within the phenomenological perspective, the preschool is seen as a life-world for the children. Preschools may widen the children's world, making the factors that affect the development as a social person more numerous and varied (Engdahl, 2007, 2011a; Meadows, 2010). The teachers in a toddler unit are given the task to produce a wide range of favourable conditions for the children. When studying the participating children, it was found that the toddlers were acting in relation to affordances in the environment. All the observed actions during the self-initiated playing were spontaneous, originating from a child or from affordances in the environment.

\section{How do the toddlers create friendship and what type of actions do they use in such a process?}

The findings also support an understanding of young toddlers as social persons. There are many events and signs leading up to this result. The young toddlers were, for example, consistently directing their interest and attention towards each other. They also seemed to be aware of each other's comings and goings and were seen greeting each other on a daily basis. Greeting behaviour involved approaching, smiles and laughter, caresses, and hugs. These mostly nonverbal children also showed recognition to the individual peers by using their names or by walking up and pointing at a photo of the child. I found that the young toddlers in this study also demonstrate their interest by actively addressing their peers. Drawing on the observations of emerging friendship among the young toddlers, it may be beneficial for the children if such relationships between friends were taken into consideration and negotiated when planning for the moving on. 
The findings in this study may also have implications for teacher education as they show aspects of young toddlers' competencies in communication and interaction and how they make friends. Well trained staff has been found to be important and related to high quality within early childhood education (Pramling et al., 2019; Višnjić Jevtić et al., 2021). The competence to understand the complex toddler interaction would make it easier for teachers to plan for achieving a balance between children's initiatives and teacher-initiated activities. Such a balance was found to be crucial for developing preschools of high quality (Sylva et al., 2010).

To summarise, the result shows aspects of young toddlers' agency within their lifeworld in a preschool. Methods for interaction used by the young toddlers, such as greetings, monitoring, attunement, taking the perspective of others and turn-taking, are the same methods for making sense and facilitating participation and understanding that we use throughout life to build friendships (Stern, 1985, 2004). However, it has rarely been previously shown how young children, during their second year of life, are able to use such competencies in a preschool setting.

Young toddlers' competencies, for example as shown in this article, are to my knowledge not commonly recognised. Although this study does not include the teachers, some observations illuminate a presence of the teachers, for instance when the playing was interrupted because of daily routines or misunderstandings by the teachers. The episode with the kicking in the hammock is one example where the teacher in the room interrupted the game, perhaps based on her understanding of the situation. When I later transcribed and analysed the observation, I found these two boys involved in a kicking game where none of the boys showed signs of distress. This indicates that listening, taking in the situation at hand, talking, asking, and explaining should be explored before interrupting toddlers' activities.

The relatively new situation, with toddlers being raised both in their family and in their preschool, can give young children access not only to more adults, but also to peers 
outside their families. Farrell (2005) and Višnjić Jevtić et al. (2021) refer to the new legal position of the child declared by the Convention on the Rights of the Child (UN, 1989) and argue that children through this convention have been given person status to which human dignity should be accorded.

\section{Acknowledgement}

This article is based on the research I made for my PhD-degree and has in part thus been published previously. However, some of the results emanate from a new analysis of data.

\section{References}

Corsaro, W. A. (2003). We're friends, right? Inside kid's culture. Washington: Joseph Henry Press.

Emerson, R. M., Fretz, R. I. \& Shaw, L. L. (1995). Writing ethnographic field-notes. Chicago; London: The University of Chicago Press.

Engdahl, I. (2007). Med barnens röst: Ettåringar "berättar" om sin förskola. [In the children's voice. One-year-olds 'tell' about their preschool] (Research report 40). Stockholm: Stockholm Institute of Education. Department of human development and special education.

Engdahl, I. (2011a). Toddlers as social actors in the Swedish preschool. (Doctoral thesis, Stockholm University, Department of Child and Youth Studies, Stockholm).

Engdahl, I. (2011b). Toddler interaction during play in the Swedish preschool. Early Child Development and Care, 181, 1421-1439.

Engdahl, I. (2012). Doing friendship during the second year of life in a Swedish preschool. European Early Childhood Education Research Journal, 20, 83-98. 
Farrell, A. (2005). Ethical research with children. Berkshire, GBR: McGraw-Hill Education.

Gray, H. (2004). 'You go away and you come back': Supporting separations and reunions in an infant/toddler classroom. Young Children, 59(5), 100-107.

Howes, C. (1983). Patterns of friendship. Child Development, 54, 1041-1053.

James, A., \& Prout, A. (1990). Constructing and reconstructing childhood. Basingstoke: Falmer Press.

Johansson, E. (2004). Learning encounters in preschool: Interaction between atmosphere, view of children and of learning. International Journal of Early Childhood, 36(2), 9-26.

Løkken, G. (2000). Toddler peer culture: The social style of one and two year old bodysubjects in everyday interaction. (Doctoral thesis, NTNU, Pedagogisk institutt, Trondheim).

Meadows, S. (2010). The child as social person. London: Routledge.

Merleau-Ponty, M. (1962). The phenomenology of perception. London: Routledge \& Kegan.

National Agency for Education. (2018). Curriculum for the pre-school: Lpfö 18. Stockholm: $\quad$ Skolverket. $\quad$ Recuperado de https://www.skolverket.se/publikationer?id=4049

National Agency for Education. (2020). Statistics. [Barn och personal i förskola 2019]. $\begin{array}{lll}\text { Stockholm: } & \text { Skolverket. } & \text { Recuperado de }\end{array}$ https://www.skolverket.se/publikationer?id=6542

Pramling, N., Wallerstedt, C., Lagerlöf, P., Björklund, C., Kultti, A., Palmér, H., Magnusson, M., ... Pramling Samuelsson, I. (2019). Play-responsive teaching in early childhood education. [s.I.]: Springer.

Sommer, D., Pramling Samuelsson, I., \& Hundeide, K. (2010). Child perspectives and children's perspectives in theory and practice. Dordrecht: Springer. 
Stern, D. N. (1985). The interpersonal world of the infant. New York: Basic Books.

Stern, D. N. (1990). Diary of a baby. London: Basic Books.

Stern, D. N. (2004). The present moment in psychotherapy and everyday life. New York: W.W. Norton \& Co.

Sylva, K., Melhuish, E., Sammons, P., Siraj-Blatchford, I., \& Taggart, B. (2010). Early childhood matters: Evidence from the effective pre-school and primary education project. Abingdon, Oxon: Routledge.

UN United Nations. (1989). The convention on the rights of the child. New York: United Nations.

Williams, P. (2001). Children's ways of experiencing peer interaction. Early Child Development and Care, 168(1), 17-38.

Višnjić Jevtić, A., Sadownik, A. R., \& Engdahl, I. (Eds.). (2021). Young children in the world and their rights: Thirty years with the United Nations convention on the rights of the child. Dordrecht: Springer.

Vygotsky, L. S. (1978). Mind in society: The development of higher psychological processes. New York: Harvard University Press.

Willig, C. (2008). Introducing qualitative research in psychology $\left(2^{\text {nd }}\right.$ ed.). Maidenhead: Open University Press, McGraw-Hill Education.

\section{Authors' contribution statement}

IME is the sole responsible of the final manuscript.

This article presents results of the author's Doctoral thesis, entitled: Toddlers as Social Actors in the Swedish Pre-School, defended from the University of Stockholm in 2011. Available at: http://www.diva-portal.org/smash/get/diva2:391762/FULLTEXT01.pdf 


\section{Editor se sección}

Las editoras de sección de este artículo fueron Magali Reis y Mariela Losso.

ORCID ID: 0000-0001-6741-1638

ORCID ID: 0000-0001-7395-1163

Formato de citación

Engdahl, I.M. (2021). Toddlers as social actors in early education. Psicología, Conocimiento y Sociedad, 11(1), 103-128. doi:

http://dx.doi.org/10.26864/PCS.v11.n1.5 